\title{
The shadow: alter-visibility in an empire of the seen
}

\section{John Welsh}

To cite this article: John Welsh (2016) The shadow: alter-visibility in an empire of the seen, Distinktion: Journal of Social Theory, 17:1, 57-77, DOI: 10.1080/1600910X.2015.1045426

To link to this article: http://dx.doi.org/10.1080/1600910X.2015.1045426

Published online: 22 Sep 2015.

Submit your article to this journal $\pi$

IIl Article views: 87

Q View related articles $ک$

View Crossmark data \lceil 


\title{
RESEARCH ARTICLE
}

\section{The shadow: alter-visibility in an empire of the seen}

\author{
John Welsh* \\ Department of Political and Economic Studies, University of Helsinki, Helsinki, Finland
}

\begin{abstract}
The article interrogates the concept of Multitude in capitalist society and challenges the simple notion of social exclusion as an operative force in contemporary social formations and their spatial dispositions. The Shadow will be offered as a spatial and psychosocial relational horizon of differentiation systemically inscribed into the social architecture, operating under a legitimating discourse of transparency politics. The concept succinctly characterizes the personal and social experiences of political opacity in twenty-first-century biopolitical capitalist society, and the exploitation of living labour by a topological apparatus of 'alter-visibility'. The piece explores the emergence of various 'Shadowlands' in the social materiality generated by spatial technologies of political and social control. By assuming the juxtaposing archetype of the Trickster, and a dialectical politics opened up by the Shadow's technology of alter-visibility, the article argues for the potential realization of the Multitude concept out of a personal ethical praxis and counter-conduct based on the Trickster concept against the consigning and coding power of capitalist Empire and the spatio-temporal shadowlands that it generates. The psychosocial dialectical potential in the figure of the Trickster derives from its enantiodromic confrontation with the Shadow in a critical heterotopic politics of disaster, juxtaposition, and 'schizophrenic' rebellion.
\end{abstract}

Keywords: biopolitics; capitalism; exclusion; multitude; panopticism; transparency; trickster; work

In the $17^{\text {th }}$ century, in order to impose the economic system and its ethos of work and greed in a definitive way, it was necessary to confine and eliminate the whole seamy mass of layabouts, liars, witches, madmen, scoundrels and all the other vagrant poor, a whole humanity whose very existence gave the lie to the order of interest and restraint. The new economy cannot be established without a similar selection of subjects and zones singled out for transformation. (Invisible Committee 2009, 71-2)

\section{Introduction: alter-visibility and capitalism}

At issue here is the spatiality and aesthetics of capitalism. The broad aim is constructively to critique and develop the concept of Multitude as a problematically ambiguous class concept. ${ }^{1}$ We must think on how hierarchies, differentiations, and disunities are violently structured into this always-almost emergent constellation of singularities in the capitalism of multiplicity. Principally, I take issue with two claims Hardt and Negri make of Multitude: (1) that the Multitude 'is not fragmented' $(2005,99)$; and (2) that 'capital wants to make the multitude into an organic unity’ $(2005,101)$.

\footnotetext{
*Email: john.welsh@helsinki.fi
} 
My aim is to highlight a vital strategic and dynamic feature of capitalist social relations, by which such fragmentation is repeatedly reproduced and any 'organic unity' is always purposively ambiguous and elusive. I want to bring out a relation of exclusion-inclusion in the psycho-spatial disposition of things and people that characterizes this formation towards a more radically immediate account of how individuals and groups in the Multitude are currently included in capitalist society in particular configurations. This is not to deny social exclusion per se, but to predicate that in a social existence reflexively born of global capitalist relations, there is no exteriority. Nothing evades coding, 'there is no outside to capital' (Hardt and Negri 2005, 100), though capital is not ontologically exhaustive, and thus 'nothing can escape the purview of the socius' (Surin 2010, 259). To be missed is one thing, but to be excluded is rather to be consigned, placed, and operationalized as a necessary component of the capitalist totality.

In particular, I want to account for how those over whom Empire rules are exploited (Hardt and Negri 2005, 336), ${ }^{2}$ how the topographical relationship of rule and production exploits their social productivity, and in what technological and apparatic manner this exploitation is being actualized. Though the political realization of the Multitude is constantly frustrated by this topology, I argue that one of the 'common shared elements' so essential to the definition of the Multitude $(2005,100)$, and that is claimed to be absent in the crowd, the mob, the masses, classes, or the population, is not only capable of realization in the Multitude, but is dialectically engendered necessarily by the operations of Empire's strategy of fracture and division itself, that is, what I have called the Shadow. In this sublative sense only can the Multitude perhaps be considered tendential towards an 'organic unity'.

In order to proceed thus, we must move accretionally beyond the disciplinary idiom of power that objectifies through the mode of enhanced visibility, where Bentham's fictive panoptic inspector surveys from his 'utterly dark spot' the objects of surveillance bathed in light and visibility, and where 'docile bodies' are produced 'under the gaze'. We must expand into a consideration of the emergence of rhizo-panoptic technologies that create objects of power through invisibility in regimes of bio-capitalist reproduction that take us past the disciplinary power and representation typical of industrialism and the Classical Age (Foucault 2002, 17; Dreyfus and Rabinow 1982, 25-6), and into the age of the biopolitical where 'proactive bodies' are induced by averting the gaze. 'Looking out of the window', as Bentham put it (1995, 45), enforces a grid of intelligibility that seduces our attention and assigns significance to a particular vista. However, technologies in the Society of Control under capitalistic conditions work to render phenomena invisible, simultaneously as they render visible, in social organization by a 'brutal dissymmetry of visibility' (Miller and Miller 1987, 4), or through what Roland Barthes fascinatingly referred to as 'both sexes of sight' $(1979,4)$. In the name of insurrection, we are currently exhorted to 'flee visibility' as a condition of vulnerability and to embrace anonymity as our greatest potential strength in the Multitude (Invisible Committee [2009], 112-13). But to be visible is a more ambiguous story than this, and such a formulation could just as easily be reversed.

I therefore want to consider the practices, techniques, and topology that make up a complex of alter-visibility, where objects of domination are generated and instantiated through visibility and invisibility, and where the Visible are more often privileged as oligo $\ddot{i}$ within the Multitude in current capitalistic conditions. As the power of aristocracy has always been based on the pedestal of visibility and conspicuous consumption, the capitalist oligarch and his subalterns likewise carve out positions of visibility but in a new context, that of bourgeois capitalism. This way of thinking about the fashionable 
transparency discourse helps us to grapple with a paradox: more so-called transparency, more opacity.

We exist in a contemporary capitalism endowed with more potential to secure the social and material conditions of life than ever before in the history of homo faber. However, amidst the historic morphological conditions of this capitalism, there are emergent practices and techniques of social inclusion-exclusion, the 'daily structural violence of capital' (Hardt and Negri 2005, 150), that throws up new forms of exploitation, domination, alienation, and enforced scarcity generally unrecognized for lack of up-to-date analytical lexica. How are we to understand this ongoing contradiction in capitalist societies? In what ways are contemporary social relations shrouded by a mysterium iniquitatis - Habermas's neue Undurchsichtlichkeit - within a new putative age of transparency and responsive openness that generates such an antagonism, and that then serves as the basis for workers to organize and to refuse the control in Empire (Hardt and Negri 2005, 150)?

We need to bring such contemporary, but unappreciated, experiences into general intellectual circulation against this theoretical mapping out. Social and economic life in the capitalist core states is currently being transformed in a 'Great Transformation Redux' (Fraser 2013, 119-20). Via austerity politics, the unfinished business of neoliberal utopianism as capitalist-class project is being prosecuted with a vengeance (Overbeek and van Apeldoorn 2012, 3), but with little prospect of any Polanyian 'double movement' (Polanyi 2002, 79, 136). Today, the Shadow succinctly captures a vital relation in any explanation of these current developments, or lack of them. It is to the extent that the Shadow concept can open up to interrogation, by its conceptual illumination and encapsulation of unrecognized but generalized experiences, in terms of emergent and reconstituted social relations of difference in biopolitical capitalist society, that we have a partial explanation for our paradox and perhaps some new possibilities for the political and personal ethical practice constitutive of the Multitude.

After outlining my conceptualization of the Shadow as a machinic apparatus in capitalism's topology, first psychosocially and then psycho-spatially, I shall endeavour to argue how it is that the Shadow is a strategically and tactically decisive apparatus in the topological exploitation of labour surplus in particular. This is the materialist core dynamic of its operation in capitalist society. In conclusion, I shall indicate how this operation of the Shadow engenders its own dialectical psychosocial counter in capitalist Empire, and how this might be integrated into the realization of the actuality of Multitude, beginning with personal ethical practice.

\section{Problems of the historical subject?}

Fex urbis, lex orbis - 'the dregs of the city make the law of the world'. This old adage attributed to St Jerome, and repeated by Victor Hugo, seems to clinch much of the historical trajectory of industrializing societies. It grasps the materialist sense, not of historical determinism as such, but of the historical weight of socio-economic and demographic forces that were unleashed and then disciplined by industrializing capitalism and its organizing contradictory imperatives of production. What has motivated and framed political struggle within capitalism is the tendency within industrialization towards ever-greater social inclusion of labour in particularly situated processes of capitalist socialized production, epitomized by the Factory, and into the ever-increasing circles of the economic mobilization of the productive capacities of populations. It is the historic proletarianization of labour into organized and concentrated forms of capitalist production that made a 'historical subject' of the proletarianized worker (Görz 2012, vi) and has occasioned the 
conditions for the organization of labour with the resultant emergence of working-class consciousness, mutual identification of common interest, and the means to organize on the basis of these (Marx 1990, 588-90). This is the 'historic mission' of the proletariat (Carr 2001, 65), and is something that we have witnessed in Modernity up to the second half of the twentieth century in the global capitalist core. This means that, within the historically unfolding structural conditions in capitalist production and consumption, there has been a greater prospect for organized working classes to possess some historical agency for collective change and individual counter-conduct through their co-ordinated swelling numbers. The trade union movement (Harvey 2003, 169-70) and the industrial 'infrapolitics of subordinate groups' of workers (Scott 1992,19) are expressions of this.

However, the historically changing forms of work and organization in global neoliberal and post-Fordist capitalism have neutralized the organized and agential potential in working-class movements, dispersing the historical force of the industrial masses in the global capitalist core (Görz 2012, vii). The post-industrial and oligarchic Drei-ZwittelGesellschaft is subject to a new socio-historical arithmetic that militates against the kind of historical momentum that has impelled political movements and proletarianized individuals out of the Shadow in the industrial era of capitalism. So although the 'working class' might have conceptual life left in it, the proletarianized worker as emancipatory historical subject seems somewhat antithetical to both the Multitude concept and the analysis above. Movements of struggle in our time seem unable to get beyond the historic prerequisites of categorical coherence, external definition, internal organization, and consciousness, which seem increasingly implausible in a fractured advanced capitalism (Chibber 2014).

As we shall see below, it is Hardt and Negri's bracketing of these social forces of fragmentation built into the topology of the capitalist mode of production and its social relations, and the insufficiently problematized assumption of a tendency towards 'organic unity' in the Multitude as a social subject, that perhaps lies behind the anticlimactic turn in the later chapters of their eponymous book to a discourse of universal rights, and the disappointing proffered strategies of political action based upon it. The constitutive process of unification in the Multitude as social subject is too easily assumed. To consider how and why this is the case is the purpose of this article.

We must nevertheless persist in the endeavour to 'provide critical analysis, strategic vision, and mobilizational proposals' (McNally 2009, 41), in a spirit of uncertain optimism, if we wish intellectually and politically to agitate towards the Multitude based on its identifiably 'common shared elements', despite the powerful tendency towards fragmentation I am outlining here. In order to do this, a greater interrogation of the spatial, both concrete and intangible, must be thrust into what has hitherto been the domain of the historical in Marxist discourses.

In her discussion of the oppression of colonized subjects and women in the earlymodern emergence of capitalist society and its transformational primitive accumulations, Silvia Federici rightly observed that 'imposing one's power over other people is not possible without denigrating them to the point where the possibility of identification is precluded' $(2004,221)$. But how does this dissociative 'othering' come about in a manner that obviates, delays, or bypasses the dialectical movement inherent to relations of exploitation, thus frustrating the realization of 'organic unity' in the Multitude? Similarly, the consciousness of relations of domination and exploitation, on the part of those touched by them, that feeds into the counter-strategies and tactics in James C. Scott's 'public transcripts' seems to be neutralized by the awesome subtleties of the Shadow's nevertheless potent operation. Unlike the 'thicker mask' worn by the more menacing power of early capitalism (Scott 1992, 3), and the 'campaign of terror' necessary for the reconstitution 
of the colonized and gendered subject of exploitation in the early-modern capitalist 'construction of their new social function' (Federici 2004, 102), the Shadow in its psychospatial sophistication seems to be a constantly reinvented innovation of advanced capitalism towards the same function.

Following Deleuze's philosophical prescription, my formulation of the Shadow is an effort to create 'new concepts for unknown lands' (Deleuze 1995, 103), in this case Shadowlands of experience and situation. This is part of Hardt and Negri's claimed agenda to achieve a 'paradigmatically materialist operation' to 'give new names to new phenomena' (Hardt et al. 2002, 181). The Shadow is offered as a modest corrective to that 'lack of concrete insight' with which the Multitude and Empire concepts have variously been charged (Zizek 2001, 192-3). The aim in discussing the Shadow is intellectually 'to bring into being that which does not yet [conceptually] exist' as a particular concept (Deleuze and Guattari 1994, 147). This is a necessary task in social and political theorizing, and more precisely I am trying 'to create concepts as the meanings for experiences' (Semetsky and Delpech-Ramey 2012, 74). I am aiming here to consider biopolitical production not through ideal forms but out of 'the dense complex of experience' (Hardt and Negri 2000, 30), towards which the Shadow is a conceptualization. This is a chaotic working out, a groping forward, in order to get 'beyond inadequate ideas' and so reach a 'plateau of adequate ideas' (Buchanan 2000, 6). Because such concepts as the Shadow usually 'remain dead and irrepresentable to anyone who has not experienced them' (Jung CW9, para. 485), the experiences of all those from stay-at-home parents and commuters to abused colleagues and social media junkies ought therefore no longer be muttered sotto voce but shouted from the roof-tops. This is to bring out the 'collective hidden transcript' that definitionally exists as implicit counterpart to Scott's 'public transcript', and which, in its collective form, 'is so essential to any dynamic view of power relations' (Scott 1992, 9). Recall, it is 'the act of consciousness, the elucidation of what is silent, ... the illumination of the element of darkness that cuts man off from himself that constitutes the content and form of the ethical' (Foucault 2002, 357). This article is an effort to furnish such experiences with a conceptual articulation. So what is the psychosocial and spatio-material Shadow, and how does it operate?

\section{The psychosocial shadow}

As a point of departure, I work on the assumption that for social production and reproduction to take place, libidinal energies have to be coded/recoded in rhizomatic synthesis so that subjects can be conditioned for their social roles and functions on the terrain of the socius (Deleuze and Guattari 1983). Jung's archetype of the Shadow offers an intellectually colourful and politically evocative starting-point for mapping out the individual's becoming in this capitalist socius. The Shadow is then a rhizomatic semiosis, deterritorializing/reterritorializing between the schizophrenic aleatory free play of 'unlimited semiosis' (Holland $1999,2)$ and the paranoid fixity of a constellated and a consigning capitalist Empire-of-theSeen, wherein the coding/recoding of identity and difference is a necessarily dialectical process within the rhizomatic. ${ }^{3}$ It is out of this dialectical dualism of rhizomatic capitalism, between its dimensional 'lines of segmentarity and stratification' and its 'collective assemblages of enunciation', that the Shadow materializes (Deleuze and Guattari 2013, 22, 24). Under capitalist relations, the Shadow imposes a tracing over the map of the socius. Like an organism, the Shadow throws up a stratum on the Body-without-Organs as a phenomenon of accumulation, coagulating and sedimenting so as to extract useful labour from the Bodywithout-Organs, imposing upon it a tracing of forms, functions, ligatures, dominant and 
hierarchized organizations, but also 'organized transcendences' (Deleuze and Guattari 2013, 184).

The Shadow is a paradoxical psychosocial relation that is constitutive of Subjectification. It is a disjunction on the horizon of a relationship between 'inside and outside' in a dynamic field of folding psychosocial forces whose action inscribes a certain territorialization of desiring-production traversing the fine limits of the cogito-as-assemblage-of-intensities in the process of individuation. The Shadow is not a mystic structure of mediation, à la Freud's Oedipus (Buchanan 2000, 20-1), but a libidinal apparatus of the machinic unconscious (as coded/coding of flow) that is immanent to the psychosocial field and is transversed by means of a disjunctive synthesis 'between the realm of the unconscious and the phenomenal world of human experiences' realized conceptually and rendered conscious via the archetypal images (Semetsky and Delpech-Ramey 2012, 70, 75). I want to think of the Shadow concept as a particular configuration (or assemblage) of psychosocial relations in contemporary capitalist society made operative by material socio-political technologies and the discursive episteme they generate.

Throughout, we shall therefore speak simultaneously of two dimensions to the Shadow that come together at the territorialized horizon of the psychosocial and which touch upon the problem of visibility/invisibility: (1) the Shadow Aspect inscribed in the psychosocial; and (2) Shadowlands built objectively into the spatio-temporal materiality of the socius itself, realized by the territorialization of the Shadow Aspect, and which materialize from a kind of chiselling out, or dragging out, of 'surfaces of stratification' from the 'plane of consistency' (Deleuze and Guattari 2013, 185). These two analytically distinct dimensions can be bracketed together by conjunctive synthesis under the conceptual rubric of the Shadow, as they are both necessary predicates, and extant constitutives, of a regime of control and its operative technologies of visibility/invisibility, which in toto I name The Shadow. The Shadow Aspect and Shadowlands make up a conjunctive dualism, a dialectical Anexactitude folding between organism-signification-subject and the 'surfaces of stratification' on the socius as Body-without-Organs (Deleuze and Guattari 2013, 185).

The 'compensatory significance' in psychical individuation (subjectification) that Jung ascribed to his archetypal Shadow becomes thus a recoding of desiring-production through the so-called Inferior Function as an affective Line-of-Flight outward through the cogito-as-assemblage into the materially sensuous beyond (Jung CW9, para. 222; Deleuze and Guattari 2013, 415). ${ }^{4}$ This is a personal inferiority or 'paranoia' in the psyche that, in the absence of an immediately visible object, is transformed and pushed by the constituted-constituting Subject into a personalized moral deficiency in a nonvisible object upon which one then acts (Semetsky and Delpech-Ramey 2012, 79), implicitly and indirectly. It is on this relational horizon, or perpendicular line-of-flight, that the Shadow is generated. In terms of individual subjectification, the Shadow is so disagreeable to the folding intra-psychical relations of the cogito-as-assemblage that it has to be channelled (or folded) into the Unconscious (Jung CW9, para. 474), where it then paradoxically coagulates, is dissociated from consciousness, and 'personifies everything that the subject refuses to acknowledge about himself and yet is always thrusting itself upon him directly or indirectly' (Jung CW9, para. 284). The reluctance to confront or acknowledge the Shadow is a vital feature of the psychopathology of the individual in society. Those strategically positioned in the power relations of capitalist Empire, whom we shall encounter below, do not want to see the Shadow, talk about it, or deal with it, yet it repetitively intrudes psycho-spatially, crying out to be operationalized on the plane of the psychosocial by the material technologies of the capitalist socius. 
What interests here is that there exists such a relational unconscious social investment on the part of social subjects (Deleuze 1995, 20), that this libidinal investment-in-becoming lives dynamically on the horizon of their social and psychological existence constituting 'the thing a person has no wish to be' (Jung CW16, para. 470), and how we can creatively reimagine this inscribed tracing for analysis and political action via a personal ethical praxis. It is the subject for whom there is a Shadow that is also of importance for explaining why individuals, and groups of which they are composed, are allowing ever-new Shadowlands to grow and spread, why they are indifferent and evasive of those who dwell within them, and why subjects must be forced to acknowledge them or not at all. We do not wish to confront or acknowledge the Shadow, and it is this feature that is central for grasping its inexorable (re-)emergence as a characterization of a particular set of relations through the play of social technologies, and our seeming inability or unwillingness to fashion and mobilize a generalized, let alone organized, politics of struggle and emancipation (a Polanyian 'double movement') for those placed within it.

It is the aversion to the growing Shadow in our society - a consequent combination of the perennial Shadow Aspect and the Shadowlands contingent on the changing valorization and accumulation requirements of capital - and how this aversion suits those who are strategically positioned in the reproduction of biopolitical capitalism, that is significantly of the moment in this time of reinvigorated primitive accumulation. It is through the Shadow that those who have 'no part in anything', as Jacques Rancière points out regarding resurgent oligarchic power, can in fact have a crucially ambiguous part that is repeatedly generated by 'those whose position or qualities have the natural effect of propelling them [those others who have no part] into the nonexistence of those who have "no part in anything"" (Rancière 1999, 9). If our political aims are in realizing the Multitude, our contemporary politics must therefore discover ways to recognize, encounter, reorient, and tap into the 'overwhelming [desiring?] power-drive of the shadow' as an unavoidable 'fundamental motor' of the psychosocial, but for emancipatory ends (Jung 2002, 8; Hardt et al. 2005, 380 ). We need this in order to come to grips with the various materializations of the Shadow in today's politics (materializations that seem increasingly salient and epochal), and to bring a reluctant society into relational confrontation with its Shadow Aspect. To fail to do this is to surrender the libidinal and spatio-material economy over to the consigning operations of capitalist Empire, its imperatives of accumulation, and its preferential structural positioning of the oligarchic visible. I therefore offer the Shadow as one possible way of apprehending a significant strategic device of perpetual fragmentation in Multitude's 'organic unity'.

\section{The spatial shadow}

Having laid out the basic psychosocial operations and cartography of the Shadow Aspect, we must consider the immediate material actuality of the Shadowland with a more nuanced understanding of its functional architecture upon the capitalist socius. The social and political textures of the capitalist world-system are constantly reconfiguring, and new functional zones of darkness are being created in the Empire of capital where people are not accustomed to expect them, often very close by. Between 'globalization' and the crisis of the democratic nation-state, new forms of stratification, exclusion, spatial reconfiguration, ideological legitimacy, lifestyle vergence, and power are emerging from the tensions and fissures. Gone are the chimeric one-nation rising-tide of the twentieth century and the easy general assumption of a single social referent within the nation-states of the capitalist core. 
We can think of these developments as constituting new geographies of centrality and marginality that cut across the old divide of poor/rich countries, and new geographies of marginality that have become increasingly evident not only in the less developed world but inside highly developed countries. (Sassen 2000, 85)

This epochal transformation is creating social interstices into which much (a)social activity is being carefully consigned to a far greater extent than is usually recognized. It is not only the case that since the Berlin Wall came down new 'walls' have been materializing (Zizek 2009, 3), often within the nation-states themselves, but that new defilades and dark spots are emerging also. It is not with walls alone that we ought to be concerned, but the twilight horizon separating social umbra from penumbra. They are less conspicuous than walls, but equally real and effective.

The Shadow (Shadowlands) must be understood as constitutive of a dynamic social architecture that has arisen to 'ensure a certain allocation of people in space, a canalization of their circulation, as well as the coding of their reciprocal relations' (Foucault 2000b, 361-2). This means that the Shadowland is an element in space, where individuals and groups are consigned into a set of social relations to bring about some specific effects, effects driven by the historical imperatives of biopolitical global capitalism under neoliberal ideological hegemony. Principally, this is the effect of separating individuals from the product of their labour simultaneous to their pacification, by establishing and inculcating into them a 'spatio-temporal identification' (Federici 2004, 143). The Shadow is predicated on both light and darkness, and arises from the relation between the two. It can only exist with both, for the Shadow is defined by what lies without it as well as within it. The Shadow (Shadowland) is not an absence, nor strictly a presence; it is a relational horizon of discretional differentiation between one medium or plane and another, and thus the bodies within or upon them. This is necessary for capitalist accumulation strategies to play out through a social and ontological mereology of identity and difference, and thus to resolve spatio-temporal crises of capital accumulation within the governmental rationality of the capitalist socius-as-order, by establishing new boundaries between the public-political-legitimate and the private-apolitical-illegitimate in the physiological infrastructure of capitalism.

In our own societies of the capitalist core the enclosure of space and the creeping segregation of domains of life proceed subtly, unnoticed, tacitly accepted, and powerfully driving what was once dubbed the 'South-Africanization' of society (Görz 2012, 13). We see the creation of gated communities and the establishment of civic spaces that de facto exclude yet carefully include groups and activities in subtle configurations. Public buildings increasingly being under lock-down or requiring special terms of entry is a phenomenon more and more common. ${ }^{5}$ The spatial separation of people engineered through the technologies of civic development, police control, organized leisure, transportation, and the relations that they reinforce are systematically inscribed into new differentiations in space that allow and guarantee the avoidance of socially subversive or politically controversial juxtapositioning. These spatial reconfigurations are part of the creation of circuitous Shadowlands into which people can be placed without the need for guards or walls (and thus the provocative disciplinary surplus that such superannuated and inefficient techniques engender), but which maintain the necessary semi-porous relational membranes that are essential for those in the Shadowland to continue as unacknowledged components of 'the productive process' and the reproduction of biopolitical capital.

What the careful spatial creation of the Shadowland achieves in relational terms, by avoiding the unpleasurable act of juxtapositioning, is the dissolution or preclusive anticipation of socially subversive heterotopias that are disturbing and that take the form of 
'contradictory sites' (Foucault and Miskowiec 1986, 25). These are 'those singular spaces to be found in some given social spaces whose functions are different or even the opposite of others' (Foucault 2000b, 361), and constitute counter-sites effectively enacting a utopia in which the real sites (all those other real sites that can be found within the culture) are 'simultaneously represented, contested, and inverted' (Foucault and Miskowiec 1986, 24). Just as the confrontation of the Ego with the Shadow is necessary for the addressing of psychological neurosis/paranoia, the heterotopia is 'capable of juxtaposing in a single real place several spaces, several sites that are in themselves incompatible' $(1986,25)$, in a kind of spatial schizophrenia. But just as all manner of spaces in work, in public, in leisure, are being terraformed within a discourse of inclusion and a transparent 'opening up', a simultaneously subtle enclosure is creating the kinds of shadows that preclude disturbing juxtaposition in favour of a particular and repetitively closing socio-spatial syntax (Foucault 2002, xix). In this regard, rather than being puerile irrelevancies, the Occupy movements and various breeds of gate-crasher groups are a significant element of any struggle to provoke vital schizophrenically 'disastrous' juxtapositions, and so problematize the spatial dispositioning of the Society of Control. One ought not overemphasize the effects, but, in the absence of clearly articulated and formulated organized activity, they do at least conjure a more visible juxtapositioning than routine canalizations and flows in those spaces. It is a beginning, to make visible that which flows invisibly.

What we must do at this point is to situate the production process, and the exploitation of living labour, in this psycho-spatially composed materiality of discipline and control. It is now on the basis of this material and spatial architecture of the Shadowland that we can develop a psycho-spatial understanding of how the Shadow constantly separates the invisible (illegitimate/unremunerated) reproduction of labour-power and 'unproductive' labour from the visibly 'productive' (legitimate/remunerated) realization of value captured through commodity exchange and other shadowy devices.

\section{Shadow labour}

The labour force is thus split into two major categories: a central core made up of permanent and full-time employees, who are occupationally versatile and mobile, and, around that core, a sizeable mass of peripheral workers, including a substantial proportion of insecure and temporary workers with variable hours and wages. (Görz 1999, 48)

Over 30 years ago, in the twilight of Fordist production, Ivan Illich based Shadow Work in conventional labour not only as 'the time, toil and effort that must be expended in order to add to any purchased commodity the value without which it is unfit for use' (Illich 1983, 22), but also adding that shadow work is that 'unpaid work which is unique to the industrial economy'. Illich envisaged that it would come to form the basis of an apartheid society characterized by a 'fundamental bifurcation of work that is implicit in the industrial mode of production' (Illich 1981, 99). Personal and social reproduction via remuneration through the prism of the wage-contract crystallized through the early-modern looking glass of the seventeenth to nineteenth centuries and through its effulgent new-found respectability pushed all other forms of work into the shadow of illegitimacy (1981, 104). In this genealogical view Shadow Work should therefore be understood, within this historical panorama of capitalist society,

to designate a social reality whose prototype is modern housework. Add the rising number of unemployed to the increasing number kept on the job only to keep them busy, and it becomes 
obvious that shadow work is by far more common in our late industrial age than paid jobs. By the end of the century, the productive worker will be the exception. (Illich 1981, 113)

He seems to have been more or less correct. Work such as babysitting, family cooking, commuting, or even the use of self-service checkouts at supermarkets is unproductive in itself, but facilitates productive (and therefore remunerated or rewarded through the commodity or wage-contract form) work in others. ${ }^{6}$ It is the servitude on which the selectively privileged 'productive' worker can then operate and, as such, conspicuously contribute to the creation and realization of value. Shadow work usually requires self-discipline rather than the discipline of the work-place, and it is increasingly essential to the functioning of the economy. For wage-labour you are selected, you apply and qualify; into shadow work you are placed and are diagnosed (Illich 1981, 100).

Shadow work is a central technique of the capitalist mode of reproduction in obfuscating the boundary between the public and private economies, and therefore legitimate and illegitimate political spaces, and is an essential component of the new social configurations of the 'risk society', 'liquid modernity', and the labour flexibility discourse.

The role of the Shadow in the recurrent generation of this fundamental bifurcation in capitalist social relations can be grasped through a historical Verfremdungseffekt. Let us look back to the great era of primitive accumulation and dispossession in the emergence of capitalist society. Silvia Federici (2004) has shown that the emergence of capitalist relations of production in late-medieval to early-modern European society was profoundly predicated on the 'enclosure of women' (Illich 1981, 107), as well as beggars, transients, and of course sheep. As an illustration, one territorialization of this enclosure was vectored through the great witch crazes, as an early-modern patriarchal reterritorialization of a medieval regime of reproduction under deterritorializing disintegration - the so-called Crisis of Feudalism. As men came increasingly to monopolize the newly emergent prestigious forms of commodified labour (wage-labour), the hitherto valued (recognized), necessary, and integrated work of women in the subsistence of the household - in a division of labour that was commonly not gender-specific, and where women controlled or dominated certain domestic and public spaces - was increasingly relegated and consigned into the shadow of non-wagework (Federici 2004, 25, 75). One tropic device through which this was accomplished and legitimized was the reterritorialization of the imago of the Witch onto variously vulnerable and threatening occupational and social categories of women. Where previously a greater proportion of men and a broader socio-cultural spectrum of women had fallen victim to the gibbet as witches, in the early-modern transformational politics of primitive accumulation those rebellious and obstreperous women who resisted their new dispossessed social position came to make up the majority of accused and tried witches. Onto the Witch, as Shadow Aspect of the emergent wage-work division of labour that was deterritorialized and reterritorialized from the semi-familiar historical debris of a social template, there was materialized an Inferior Function of a reconfiguring and resurgent patriarchal society of men increasingly proletarianized off the land into wage-work, for whom the subordinated 'unproductive' were a potential threat to their new domination over women as compensation. ${ }^{7}$

Simply put, this is the 'patriarchy of the wage' as a structural alter-visibility at the core of modern capitalism (Federici 2004, 68, 97-100). Indeed, it is no coincidence that the assignation of 'witch' tended to gravitate towards those treated as the old, unfecund, 'unsound', or superfluous, as well as the conspicuously and vocally disobedient. That is, those women who had to be ousted from social, occupational, vocational, and proprietorial (thus public and visible) positions now deemed offensive to the new patriarchy (i.e. 
midwives, unmarried female property owners, medical 'wise women', etc.). These were now the 'unproductive' understood in contrast to the new commodified labour form, that is wage-labour, but with indirect disciplinary effects for all categorical women.

The discourse of the Witch served to differentiate women, to assign a private gender role, to objectify the female body, to make it suspect and 'everything that the subject refuses to acknowledge about himself', and to push it in absentia into the Shadow as femina domestica. In this way, the line-of-flight of the witch imago constituted one of many mechanisms for hiving off discredited 'woman's work' into the shadow and the invisible privacy of the now male-dominated home (Federici 2004, 75), and for elevating into the light of public acknowledgement, visibility, and legitimacy the world of the heroic wageearner - Man, vir laborans. This legitimated one of the many penumbraic boundaries (or membranous horizons of differentiation) necessary for continuous primitive accumulation of capital and therefore capitalist reproduction, in accordance with the Inferior Function of the Shadow Aspect, this time within the very walls of the home itself as a vertex of (a)social exploitation of production grounded in the simultaneous synonymizing of production and reproduction, whilst separating/dispossessing the products (thus value) of both from the woman. Then, as now, the Shadow made possible at once in the same motion 'the appropriation and concealment of women's labour' $(2004,97)$, as a device generalized and reinvented again and again when primitive accumulation is required.

The Shadow looms in our contemporary capitalist society as a similarly useful means to produce and mobilize a politics of preferential differentiation, a subtle political relation of power and domination that functions to extract/realize unacknowledged surplus from those consigned to the Shadow. In the current retreat from accumulation-by-expanded-reproduction, the old familiar strategy of accumulation-by-dispossession wears a new mask. The new 'patriarchy of the wage' furnished a historically decisive apparatus of primitive accumulation in the disintegration of feudal society and the emergence of capitalist social relations in the early-modern period. It has repeatedly served the same function ever since. This illustrative historical diversion serves simply to demonstrate a profound historical facet of capitalist social relations in another context and to draw attention to how unprecedented antagonisms between domestic and public spheres were conjured up complementary to wage-work as a 'necessary adjunct of life' under capitalism, and that this 'necessary adjunct of life' came to be monopolized by men as the new wardens of their domestic women (Illich 1981, 107). Woman consigned to the Shadow became woman without a voice, woman without a presence, woman without a history, but not woman without an unacknowledged laborious contribution to make to the creation of economic value in a socialized system of productive value realization and a freshly gendered division of labour. The Shadow's membranous horizon between darkness and light is semi-porous, but asymmetrical. With the criminalization of women's control over their own bodies (Federici 2004, 92), as with the working class in the century before them $(2004,85)$, women themselves became the commons. Their labour became a free resource, though consigned within the enclosed grasp of newly proletarianized men as compensation for their losses (enclosed land, etc.), but outside of the new public legitimacy of market relations $(2004,97)$ - social inclusion and moral exclusion.

Today, some suppose that the post-industrial heartlands of the capitalist world-system are currently experiencing the bubbling emergence of a new and ever-larger lumpenproletariat of the excluded, but this is only half the story. The Shadow is a place (space-as-flow) of positive consignation, not a nothingness that exists accidentally and outside of the social system. Activity in the Shadow is an essential feature of the functioning of the social system that has an interest in perpetuating the Shadow, in filling it up and carefully maintaining its 
relational position to the social totality. In the historical articulation of a post-Fordist capitalist milieu, a similar deterritorialization and reterritorialization of libidinal investment and meta-disciplinary control is taking place as the spatiality of the factory (and its own historically particular cartography of alter-visibility) disintegrates.

This brutally consigning power that is characteristic of capitalist social relations is therefore more than merely the technical creation of a shadowy reserve army of labour. The Shadow is a functional zone that not only serves an economic purpose, but provides an effective ideological-psychological device for the political power relations built on the horizon of differentiation between darkness and light to crystallize socially and become naturalized as legitimate. In this way, the need in a capitalist system for numbers of relative surplus labourers can be created and maintained, but without the creation of socially dangerous and politically subversive mass or 'lumpen' formations. Rather, emergent socio-political technology 'creates a mass of human material always ready for exploitation by capital in the interests of capital's own changing valorisation requirements' (Marx 1990, 784), but a mass that is fractured, invisible, dispersed, and carefully placed in subtle ways. A kind of panopticon without walls, but that is predicated on invisibility rather than perpetual visibility - an 'alter-visibility', one eye open and one eye closed as occasion requires.

The shadow worker is here constituted in a manner similar, and for purposes similar, to the constitution of the Delinquent in the rationality of the disciplinary society. Just as the necessity for there to be crime and criminality through what one might call the 'positive knowledge of the delinquent' created by the carceral system writ large (Foucault 1991, $82-9,254,272,279-81)$, the Shadow also is fabricated as a necessary anomaly in what one might call an 'economy of illegalities'. This is in order for certain activities to be perpetuated, reproduced, and indulged in by those within the lighted and visible zone of legality and public legitimacy, but without calling into question their privileged status within that zone by any explicit comparison or recognition of difference. The liminal position of 'social separation and moral connection' (Dreyfus and Rabinow 1982, 3), exemplified by the recurrent incarnation of the figurative leper in Madness and Civilization (Foucault 1973, 7), is likewise occupied by the Shadow in modern capitalism but through an inversion of the relation in capitalist Modernity (moral separation and social connection), perhaps best characterized by Hardt and Negri as simultaneous 'servile inclusion' and 'violent marginalization' $(2005,159)$.

The metaphysical vertex at the heart of all this is the cunningly opaque royal commodity relation as an immaterial unitary concept internalizing objective dialectical contradictions, and as the greatest laundering device in the history of humanity. It is the inclusion of unacknowledged shadow labour in the production of commodities, labour from which the social gaze is averted via technologies of (un)transparency so as to legitimate the absence of any reward for their labour, which sustains the greater economic surplus enjoyed by labourers outside of the Shadow and inside 'productive' wage-work. ${ }^{8}$ It is another historically manifest technique of primitive accumulation, robbery, and exploitation on the grandest scale, but worked out through 'the depths and details' of particularized experiences in the distilled extraction of absolute surplus value. It is made invisible to the exploiter of labour, and immeasurable to the producer of labour, neither of whom can any longer differentiate between work done by the labourer for herself and work done for others (Federici 2004, 29). It is for this reason that the Shadow is a historical feature of capitalist society in particular. The historical seed germ of the Shadow apparatus, and its robust subtlety of domination and exploitation, resides in the invisible but material relations through which the commodity places us one to another. 
As example, consider the Shadow in academia. Changing work practices in the University are creating new types of Shadow. The growing burden of shadow labour can be discerned in the proliferation of burdensome tasks unleashed by the greater 'transparency' of the telecommunication revolution, for instance the sheer quantity of emails that must be handled on a daily basis by academic workers that was never possible in the dark days of technologically backward opacity. The relative anonymity-at-a-distance in article submissions to peer-review journals, facilitated by totally impersonal online manuscript submission software, allows the surplus value of an article as objectivated and commodified labour to be appropriated by a publishing house which then makes significant profits from subscription fees on the back of such commodities, whilst not having to acknowledge or even encounter the unremunerated author who remains in the Shadow at the other end of a 'transparent' internet connection - a flow - and online submission processes. The hitherto proximate labourer is rendered invisible and mute.

Thus we have social inclusion (exploitation of value via commodified exchange) that is accompanied by moral exclusion. This latter takes the form of a positive disavowal of remuneration by senior academics, publishers, and administrators, based on ethical indifference to the invisible labourer. As early as the sensory geometric anthropology of Edward Hall's proxemics (1960s), it has been understood that proximate spatial encounter has a profound impact on the behavioural system characteristics of living organisms and on the ethical determinations and actions of human beings (Hall 1990). Given this, it is unsurprising that the absence of recognition on their part for this labour as the origin of value is often argued for spuriously out of the Inferior Function through a variety of apologetics that attempt to legitimate the state of affairs by some 'othering' reference to the labourer in absentia, sometimes in the form of passive vilification.

In like vein, the reaffirmation of symbolic status differentials through rankings, 'excellence clusters', and the fractioning of grant-researchers from contracted-researchers are amongst some of the techniques that establish horizons of differentiation that legitimize the consignation of certain groups into shadow activities. For example, $\mathrm{PhD}$ researchers are having work-spaces, resources, and access to working fora (conferences) denied to them through room revocations, exorbitant conference fees, and other Austerity measures. However, such researchers are simultaneously exhorted to upload their 'output' onto institutional publication databases so that the university in question can benefit from outputbased state budget allocations. In other words, their surplus is appropriated through straight primitive accumulation, while they are very reasonably consigned to the Shadow in the name of legitimate Austerity cuts. It is now a common academic occurrence that articles are produced by post-graduates and junior researchers who have to work 'from home', often having returned to their respective countries of origin due to an inability to renew funding sources, thus denying them physical access or presence in the very university which will undoubtedly seek to benefit from any surplus accruing from the creation of affiliated publications in the manner described above. Transparent communications technologies allow one to labour thousands of miles away, but without the awkward confrontation of physical presence and with no potentially subversive contact with others likewise engaged. This is another instance of the dispossession of the direct producer from the object of their labour through a socio-political technology that effects the relations of possession (Poulantzas 2014, 18). Nobody knows, for nobody sees. Such exploitative opacity is only possible due to the emergence of more 'transparent' technologies of communication. I would exhort readers to attempt to identify such shadow work in their own lives, in order to begin the process of mutual recognition and struggle against those mundane powers of Empire that consign and exploit. 
This consideration of shadow labour means that we should question the strange claim of Hardt and Negri that 'the working class ... hold no political privilege with respect to other classes of labour within the multitude' $(2005,107)$, if by this we mean between different fractions within the working class. The Shadow testifies to the perennial recurrence of just such a differentiated structure of strategically privileged position within the Multitude, whereby everyone occupies varied positions and 'certain positions preponderate and permit an effect of supremacy to be produced' (Foucault 1980, 156). I see the only hope being derived from a radical confronting of society with its shadow economy and the shadow work that nourishes it. Put simply, partners must be confronted and forced to make their share of the dinners, and professors must be made to take their share of the room cuts, for a start.

\section{Empire's dialectic}

I have presented the Shadow as a relational horizon of discretional differentiation systemically inscribed into the psychosocial architecture by myriad but identifiable techniques and social technologies that seem to be legitimized through the epistemic discourse of 'transparency', but are driven by the operative demands of the Shadow. In the constituted Shadow Subject, we thus have a sufficiently open analytical concept that does not rely upon dubious essentialist claims, does not entail internally exclusive categorical definitions that divide off traditionally excluded groups, and that does not require hierarchical organization. Remember, the Shadow is not defined by itself, but only in relation to the light, to that which resides outside the Shadow and enjoys the ontological legitimacy afforded by the contrast. This is the kind of 'common shared element' that we are looking for as constitutive of the Multitude. What constitutes the Shadow is its relation to the light ('the productive', the Self, oligoi). Those who dwell in the Shadow are not a class or (mutual) 'identity group', but perhaps une nebuleuse (Rambach and Rambach 2011), that only receives form when undergoing condensation from the perpetual aggregation of experiences that people have of being relationally constituted as the Shadow by the consignations of capitalist Empire. In this way, the shadow analytically textures the concept of the Multitude as a 'collectivity that struggles in common', but which is 'defined by the lines of collective struggle ... the lines of collective resistance to power' (Hardt and Negri 2005, 104). Remember that

The multitude, designates an active social subject, which acts on the basis of what the singularities share in common. The multitude is an internally different, multiple social subject whose constitution and action is based not on identity or unity (or, much less, indifference) but on what it has in common. (Hardt and Negri 2005, 100)

The singular relations of domination discussed in this article - the lines of the Shadow are what they have in common. The amorphous concept of the Multitude as multiplicity, which arguably lacks the coherence sufficient for concerted action, can thus be augmented by the relational, rather than substantive or normative, existence of the Shadow. No matter who you are in the Shadow, or what you do in the Shadow, those consigned to the Shadow are all in common relation to the powers of alter-visibility that consign and code them by virtue of that relation itself regardless of the concrete 'empirical differences' in singular particularity. The Shadow is an isomorphism (in lieu of archetype) in the multiplicity of forms that this relation can take in everyday life, but the experiences all share this same isomorphic relational character. To communicate, educate, and illuminate these relations of 
domination and exclusion/inclusion in terms of the Shadow has the advantage of being universally recognizable qua isomorphism for those who have experienced such relations, on the basis that 'implicit meanings become explicit by virtue of becoming conscious and by being perceived' (Jung CW9, pt. I, 4). If 'recognizing a common enemy and inventing a common language of struggles are certainly important political tasks' for the Multitude (Hardt and Negri 2000, 57), then perhaps struggle can best be articulated at this stage not as an organized action between those who must construct dubious commonalities and identity as a clear social class, something that is historically passé or perhaps encore inconnu, but rather as mutually conscious recognizant activity oriented back along the relational lines-of-flight that code and consign us to the Shadow, those power relations of domination, exploitation, and assujetissement that mark us as 'cases' for purposive collective individualization in biopolitical capitalist society (Foucault 2000a, 331).

In other words, the Shadow as an isomorphic relation of contemporary capitalism allows us to think a little beyond the three great preoccupations of political struggle in the counter-hegemonic movements of the twenty-first century - categorical identity, group consciousness, and socio-political organization. The Shadow as arising from a relation provides an experiential-relational and non-essentialist substitute for the problematic of transformative sociological categories, it elucidates and communicates the commonality of experience necessary for consciousness and the formation of evental 'communes' (Invisible Committee 2009, 101), and it substitutes a counter-object-oriented concertation for subjective categorical organization. The need is to develop a critical social consciousness of experiences, a kind of political action reconfiguring the social field of experience as part of a Subjectification through the 'disorder of revolt' contributory to the realization of the Multitude (May 2010, 78).

Realizing this critical and socially mutual consciousness of the relational Shadow as the 'common shared element' necessary for the Multitude is not simply wishful thinking. The Shadow mobilized as a dispositional assemblage of capitalist Empire engenders its own dialectical counter. Even in its Jungian origination, as in its 'collective, mythological form', the individual Shadow was recognized as relationally bound to a dialectical psychosocial movement, containing within it the 'seed of an Enantiodromia, of a conversion into its opposite' (Jung CW9, para. 488). Because experience is not confined to the individual Cogito of a Cartesian subject but is socio-cultural and always involves the other, the integration (but not reconciliation or transcendence) of such a generic 'other' is paramount for the understanding and revaluation of such an expanded experience (Semetsky and DelpechRamey 2012, 78), not so much to reconcile and stabilize, but to disturb the neurotic into the schizophrenic. ${ }^{9}$ This dialectical counter-actualizes the experiences of being constituted by the Shadow itself, psychosocially in the individual psyche, and objectively by the various responses to individuals' concrete experiences of being subjected to the apparatuses of alter-invisibility. Just as the Shadow inexorably intrudes into the individual psyche, the individual in the social condition of alter-visibility cannot be rendered completely invisible. To the extent that they are made conscious of their ambiguous positionality, the isomorphic relation as the 'common shared element' they have with others realizes and actualizes the Multitude.

The Shadow is, however, capitalism's imperfect solution to its own contradictory and paradoxical imperatives. It can never be defeated, avoided, obviated, but it can be sublated through constant negation, that is, perpetual struggle. Despite its potent subtleties, it is but a temporizing mechanism. In the case of our early-modern witches, a dialectical appropriation of the coding consignation has repeatedly stimulated antithetical and sublating counter-movement (Federici 2004, 10-11, 174, 193). 
However, those of us who dwell increasingly in the shadowlands of this article have to derive our own political and social strategies of engagement to push this dialectical movement. There can be no mere retreat into interiority. This means that though what used to be called the 'objective conditions' for social struggle that result from the very functioning of this capitalism are not currently propitious (Mandel 1971, 25), there is still possibility. The main strategic and tactical issue right now, if we wish to promote a realization of the Multitude concept, is to illuminate both the mundanely tactical and the conspicuously strategic consigning isomorphic relations of alter-visibility that is the Shadow, to make visible the invisible through thought, speech, and action, and to focus immanently critical analysis into the gap between the two.

Forging a dialectical space can create historic conditions of possibility in the face of cynical demoralization. The spreading material existence of shadowlands in the productive economy might not suggest a revival of the categorical historical subject of social transformation in the form of the proletarianized worker, but it might well immanently occasion the opportunity for a generalized move away from the socialized norm of wage-work altogether with more and more persons taking on shadow roles 'uncoupled' from the measureable productivity of wage-work, and into genuinely autonomous activity (Görz 2012, 13), 'owning' the Shadow, so to speak. This is a matter of political struggle, engagement, activity, and courageous thought. Hic Rhodus, hic salta! In the meantime, we can turn to the problem of the personal ethical practice at the heart of any emancipatory common struggle for autonomy from Empire's consignations. Such is the source of the constitutive power (potentia) of the Multitude, by which the individual might escape placement in the Shadow where she otherwise regards her situation depressingly under the yoke of a malignant 'capitalist realism' (Fisher 2009)

\section{Personal ethical practice: the trickster}

Having elaborated the topological alter-visibility in the Empire of capitalism, and its implications for the realization of Multitude in the face of dynamic fracture and division, it remains to say something credible on how the consigning powers of capitalist Empire might be countered by the individual, and how the fragmentation of the Multitude might be resisted. Taking us back to the original problem, I claim that Multitude is not necessarily fragmented, but is contingently rendered so again and again by the operations of the Shadow, a Shadow whose enantiodromic negation or counter is always being generated dialectically. So how can this negation or counter be articulated and actualized in a practice of ethical counter-conduct?

Various templates and exempla of personal ethical practice suggest themselves, often of classical provenance. However, when it comes to the subjective conditions of our existence in the Shadow, I can offer two initial options appropriate to the idiom: to play the Idiot or

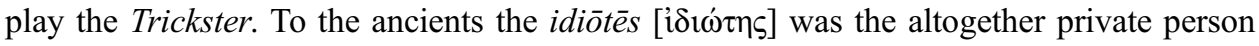
who cannot, will not, does not take part in the negotia of political life. Those consigned to the Shadow, into the socially invisible and politically illegitimate zone of the private under capitalist relations, are rendered politically 'inactionary' but simultaneously are rendered economically proactive and systemically necessary, encouraging what Wright Mills identified as a 'spiritual condition of malaise' concurrent and consequent to the non-stop inertia of their material proactivity $(1970,51)$.

There is another Jungian archetype which engages most effectively with the Shadow, and that is the Trickster. Perhaps we in the Shadow must learn to be Tricksters, representing the Mephistophelean true spirit of life (Jung 1983, 262). This is the direction of a libidinal 
movement decisively deterritorializing the Shadow. Again derived from Jung, the Trickster archetype originated as a 'psychologem', a profoundly ancient archetypal psychic structure (Jung CW9, para. 465), a nonconformist rebel that uses irony, ruse, and paradox and who stimulates reflection and wonder, opening up novel perspectives on reality (Kosteras 2013, 172). The importance of the Trickster is that it has the enantiodromic capacity to disrupt the flow of the Shadow, and potentially begin a new rhizome. For though the Trickster is itself a 'collective shadow figure, a summation of all the inferior traits of character in individuals' (Jung 2003, 177), the collective figure of the Trickster can construct itself out of the everpresent Shadow as a component of the social personality.

In contrast to the Shadow, the Trickster is pleasurable and therefore not conducive to repression or the demoralization that is such a salient feature of life in the Shadow, actively sustaining consciousness and attention. It is highly conducive to Foucault's admonition not to assume that one has to be sad to be militant, despite the abominable nature of the thing one is struggling against (Foucault 2008, xiii). The Trickster therefore offers a counterconcept of personal ethical practice, a counter-actualization and an ethics-of-joy, a new ethos devoted to the integration of the Shadow as a mode of existence for the individuation of the constituted-constituting Subject in terms of a Deleuzean actually becoming-other (Semetsky and Delpech-Ramey 2012, 79). This is that increasingly necessary critical stance which is 'more light-hearted, more playful, than the austere proletariat of [bygone] Marxist theory' so disdained by Jacques Rancière $(2011,8)$.

Indeed, the Trickster is a potentially plausible method of forcing the Shadow Aspect of oneself and others into consciousness and subjecting it to a conscious criticism (Jung CW9, para. 474). The potential of the Trickster to confront the Shadow is realized through various 'disasters' or dialectical collisions that derange and disrupt the canalizations in the regime of alter-visibility, and bring out its paradoxes. It is from these 'harrowing' psychological 'disasters', the refusal of any denial, the disruption of repressive territorialization and its line-of-flight flowing through the cogito, that psychosocial recognition and sublation of the Shadow can be countenanced (Jung CW9, para. 487), and by which the Trickster 'may open people's eyes' (Kosteras 2013, 172). Perhaps it is true that 'visibility must be avoided' as an interim tactical assumption (Invisible Committee 2009, 114), but it is ultimately self-defeating in an Empire-of-the-Seen where visible confrontation seems a sine qua non of political existence.

The Trickster may appear inconsequential, but that is to underestimate the destabilizing and mobilizing energy of the Trickster's amorality and recklessness as a type of counterconduct, a dissidence or 'insoumission' that enacts resistance to those forms of power not exercising sovereignty, but 'conduct' (Foucault 2007, 200), and in this case that consign according to the mutable needs of capitalist Empire. This is something similar to Deleuze and Guattari's 'Schizophrenic' as a socially unassimilable being (1983), and Hardt and Negri's 'New Barbarian' (2000, 214-18), that strives to evade the codifying consignation imposed upon it by the socius of capital.

Finally, the Trickster does not have a categorical content and is of no specific gender, sexuality, race, age, or soma. It is also a polymorphous formation, appropriate for the nonhierarchic dynamism of rhizomatic ordering characteristic of Multitude's ontology. In this way, the archetype has a potential to mobilize and relate disparate experiences and flows unhampered by the baggage of a particular, parochial, or fixated categorical subjective content, simultaneously opening up both universal horizon and heterotopic space, generating ongoing enantiodromic dialectical 'disasters'. Complementarily, this is a staging of those in the Shadow as a Rancièrean partage, an 'event of appearance' (Panagia 2010, 103), the creation of sensible (aesthetic) collisions that combat the status of invisibility. 
What does this mean in carbon terms? This is not merely a politics of recognition, this is a politics of rebellion and manifestation. For just as the capital surplus, as Nye Bevan once remarked, is actually 'a million and one surpluses in the possession of as many individuals' (Bevan 1952, 59), so must disasters, as provoked by the Trickster against exploitation of the surplus, be understood as a million and one disasters provoked throughout and across the plateaux of our daily lives as a field of possibilities where 'responses, reactions, results, and possible interventions may open up' (Foucault 2000a, 340). Once again, the Multitude is most propitiously realized out of personal ethical practice. Assuming that the power of resistance cannot be homologous to the power that oppresses (Hardt and Negri 2005, 90 ), we are therefore talking about doing violence to confront society with its Shadow, but a Benjaminian 'divine violence' (Benjamin 1995, 277-300). Rather than being dependent on the 'master's tools', as has been so often the case in post-colonial and inter-gender struggles (Federici 2004, 232), the Shadow prescribes for its antagonists its own non-homologous negation - the Trickster. Beyond Hardt and Negri's utterly inadequate principle of 'violence in self defence' $(2005,343)$, this is rather a violence that undermines the normal functioning of the State or regime of codifying assemblages, in contrast to a prosaic 'mythic violence' as a normal and daily reproducing stage play, and can in fact be entirely passive. It is a great refusal, a sloughing off, an unwillingness to be so coded, consigned, and mobilized by the Shadow's dynamic.

\section{Conclusion}

The intention in this article has not been to conjure up a concept with revolutionary transformative pretensions. I have merely attempted to conceptualize an implicit and common set of relations in the topology of capitalist society that many experience, but few recognize or discuss. I have concluded by trying to suggest at least a minimal means by which mounting demoralization for many can be converted into personal ethical practice as the basis for any future political action or realization of the Multitude in whatever political form it might be actualized. To those who would question the political effectiveness of personal ethical practice, one might answer in Hardt and Negri's own words that 'it is useless to rack our brains over whether a proposal is reformist or revolutionary; what matters is that it enters into the constituent process [of realising Multitude]' $(2005,289)$.

What is certain to me is that Multitude will only ever have the potential to confront, counter, and refuse the coercive powers of Empire, that simultaneously precede and succeed it, if the operations and apparatuses that constantly fragment it against itself, turning living labour against living labour, can be illuminated and discussed by those consigned under its dynamic. This is what I have attempted.

Perhaps the most fundamental theoretical contribution of the Shadow therefore resides in its analytical opposition to Hardt and Negri's assertion that it is the tactical manoeuvres of capitalist Empire that are necessarily secondary and responsive to the morphology of living labour $(2005,146-7)$. For them, it is biopolitical labour that necessitates and stimulates biopolitical capital to be adaptable and versatile in its violent coercions and manipulations. However, the Shadow suggests that such a unidirectional causality is questionable, and that the movements and transformations of living labour have psycho-spatial structures waiting for them on the dialectical battlefield of historical capitalism.

\section{Disclosure statement}

The author has no conflict of interest to disclose in this research. 


\section{Notes}

1. In contrast to the unitary concept and identity of 'the people', Multitude is constituted as a plural and differentiated set of singularities that 'cannot be reduced to sameness'. It is a constantly reconstituting social subject that 'acts on the basis of what the singularities share in common' within the context, and through the operations, of Empire (Hardt and Negri 2005, 99-100).

2. Here I take Empire as a tendency of global political order, through which a topological infrastructure is constantly reproduced that places and canalizes individuals in the biopolitical population according to capitalist imperatives. Strategically, it is a network power of hierarchies and divisions in which nation-states, corporations, and supranational institutions are the principal nodes. Tactically, it is a cartography of mechanisms and apparatuses of control that operate through the technical and practical depths and details of disciplinary and governmental power in a capitalist mode of production, consumption, distribution, and exchange (Hardt and Negri 2000, xii-xiii).

3. 'The rhizome is any network of things brought into contact with one another, functioning as an assemblage machine for new affects, new concepts, new bodies, new thoughts; the rhizomatic network is a mapping of the forces that move and/or immobilise bodies' and which contribute to 'the formation of a plateau through its lines of becoming, which form aggregate connections' (Colman 2010, 233).

4. Consciousness here is a name and not a representation. Rather than an entity or subject, here it is understood as relatively stable activity, properly an assemblage of such activities, or, further, an assemblage of intensities. If the unconscious is 'uncoded flow'/desire (Buchanan 2000, 4), consciousness is the assemblage of intensities of libidinal flow. An assemblage is a 'constellation of singularities and traits deducted from the flow' (Deleuze and Guattari 2013, 406).

5. The new and much vaunted Information Commons building (centralized library and IT facilities) at the University of Sheffield, UK, is an ironic case in point. Replacing spaces interior to various buildings across campus that before were physically (and more informally) accessible from the street, the new Information Commons is actually an enclosed and privatized space, complete with security turnstiles at the entrance, accessible now only to fee-paying student-clients and contracted staff who possess pass-cards.

6. 'Productive labour' is labour the value of which is realized through the exchange of labour as commodified labour-power. 'Unproductive labour' is that which creates value, but which is not realized through such commodity exchange as commodified labour-power. Whilst agreeing with the basic position of Hardt and Negri that 'all forms of labour are today socially productive' $(2005,106)$, my formulation would comprehend their meaning of 'socially productive' to mean 'socially reproductive', creating a space for a more nuanced and specific meaning in this analysis reserved for the term 'productive' in the manner I have outlined above.

7. In an expanded system of commodified exchange, such as a capitalist society is, the privileged position of 'the productive' is repeatedly threatened by the proximate existence of 'the unproductive' as their alter-ego, potential replacement, shadow aspect, etc. Furthermore, the appropriation and projection of the witch imago intercepted the constant threat of the restoration of the woman's body to her own possession. A fictive social danger is contrived to legitimate the destruction of a real one to the new patriarchy.

8. I ought to make it clear that the 'productive' and 'unproductive' are not so much discrete persons, but rather personae or roles that individual persons can move in and out of as 'bearers' (Träger) of relations.

9. To Deleuze and Guattari, the diagnosis of the schizophrenic in Freudian psychoanalysis arises from the patient's resistances to being oedipalized and thus disciplined by the psychoanalyst (Deleuze and Guattari 1983, 54). To them, however, the schizophrenic is arguably that of the productive unconscious that eschews and struggles against consignation, coding, diagnosis, canalization, and mobilization of their libidinal investments. As such, the schizophrenic offers a greater potential for confrontation with the Shadow's psychosocial coding and recording of desiring-production.

\section{Notes on contributor}

John Welsh is a researcher at the Social Science Faculty, University of Helsinki. His main research interest is on the aesthetic ontology of advanced capitalism, and its strategic and tactical topological operations. He is currently concluding $\mathrm{PhD}$ research on academic rankings as spatio-temporal regimes of accumulation in historical capitalism. 


\section{ORCID}

John Welsh (D) http://orcid.org/0000-0002-7136-1001

\section{References}

Barthes, R. 1979. The Eiffel Tower and other mythologies. New York: Hill and Wang.

Benjamin, W. 1995. Reflections: Essays, aphorisms, autobiographical writings. New York: Schocken Books.

Bevan, A. 1952. In place of fear. London: William Heinemann.

Bentham, J. 1995. The Panopticon Writings. London: Verso.

Buchanan, I. 2000. Deleuzism: A metacommentary. Durham, NC: Duke University Press.

Carr, E.H. 2001. The twenty years crisis: An introduction to the study of international relations, 1919 1939. Basingstoke: Palgrave McMillan.

Chibber, V. 2014. L'universalisme, une arme pour la gauche. Le Monde Diplomatique, May. No. 722 : $1,22-23$.

Colman, F.J. 2010. Rhizome. In The Deleuze dictionary, ed. A. Parr, 232-5. Edinburgh: Edinburgh University Press.

Deleuze, G. 1995. Negotiations 1972-1990. New York: Columbia University Press.

Deleuze, G., and F. Guattari. 1983. Anti-Oedipus: Capitalism and schizophrenia. London: Continuum.

Deleuze, G., and F. Guattari. 1994. What is philosophy? New York: Columbia University Press.

Deleuze, G., and F. Guattari. 2013. A thousand plateaus: Capitalism and schizophrenia. London: Bloomsbury.

Dreyfus, H.L., and P. Rainbow. 1982. Michel Foucault: Beyond structuralism and hermeneutics. Chicago, IL: Chicago University Press.

Federici, S. 2004. Caliban and the witch: Women, the body and primitive accumulation. Brooklyn: Autonomedia.

Fisher, M. 2009. Capitalist realism: Is there no alternative? London: Zero Books.

Foucault, M. 1973. Madness and civilization: A history of insanity in the age of reason. New York: Vintage.

Foucault, M. 1980. The eye of power. In Power/knowledge: Selected interviews and other writings, 1972-1977, ed. C. Gordon, 146-65. New York: Pantheon Books.

Foucault, M. 1991. Discipline and punish: The birth of the prison. London: Penguin.

Foucault, M. 2000a. The subject and power. In Essential works of Foucault, 1954-1984. Volume 3: Power, ed. J. Faubion, 326-48. London: Penguin.

Foucault, M. 2000b. Space, knowledge, and power. In Essential Works of Foucault, 1954-1984. Volume 3: Power, ed. J. Faubion, 349-64. London: Penguin.

Foucault, M. 2002. The order of things: An archaeology of the human sciences. London: Routledge. Foucault, M. 2007. Security, territory, population: Lectures at the Collège de France, 1977-78. Basingstoke: Palgrave Macmillan.

Foucault, M. 2008. Preface. In Anti-Oedipus: Capitalism and schizophrenia, ed. G. Deleuze and F. Guattari, xi-xiv. Minneapolis, MN: University of Minnesota Press.

Foucault, M., and J. Miskowiec. 1986. Of other spaces. Diacritics 16, no. 1: 22-7.

Fraser, N. 2013. A triple movement? Parsing the politics of crisis after Polanyi. New Left Review 81: $119-32$.

Görz, A. 1999. Reclaiming work: Beyond the wage-based society. Cambridge: Polity Press.

Görz, A. 2012. Capitalism, socialism, ecology. London: Verso.

Hall, E.T. 1990. The hidden dimension. New York: Anchor Books.

Hardt, M., and A. Negri. 2000. Empire. Cambridge, MA: Harvard University Press.

Hardt, M., and A. Negri. 2005. Multitude: War and democracy in the age of empire. London: Penguin.

Hardt, M., A. Negri, N. Brown and I. Szeman. 2002. The global coliseum: On empire. Cultural Studies 16, no. 2: 177-92.

Hardt, M., A. Negri, N. Brown and I. Szeman. 2005. What is the Multitude?. Cultural Studies 19, no. 3: 372-87.

Harvey, D. 2003. The new imperialism. Oxford: Oxford University Press.

Holland, E.W. 1999. Deleuze and Guattari's Anti-Oedipus: Introduction to schizoanalysis. London: Routledge.

Illich, I. 1981. Shadow work. London: Marion Boyars. 
Illich, I. 1983. Gender. London: Marion Boyars, London.

Invisible Committee. 2009. The coming insurrection. Los Angeles, CA: Semiotext(e).

Jung, C.G. 1953-1979. Collected works of C. G. Jung, Vols. I-XX. Princeton, NJ: Princeton University Press. [Cited as CW throughout.]

Jung, C.G. 1983. Memories, dreams, reflections. London: Flamingo.

Jung, C.G. 2002. Essays on contemporary events, 1936-46. London: Routledge Classics.

Jung, C.G. 2003. Four Archetypes: Mother, Rebirth, spirit, trickster. London: Routledge Classics.

Kosteras, M. 2013. Organizations and archetypes. Cheltenham: Edward Elgar Publishing.

Mandel, E. 1971. The formation of the economic thought of Karl Marx: 1843 to Capital. London: NLB.

Marx, K. 1990. Capital: Volume 1. London: Penguin.

May, T. 2010. Wrong, disagreement, subjectification. In Jacques Ranciere: Key concepts, ed. J. P. Delanty, 67-79. Durham, NC: Acumen.

McNally, D. 2009. From financial crisis to world slump: Accumulation, financialisation, and global the slowdown. Historical Materialism 17: 35-83.

Miller, J.-A., and R. Miller. 1987. Jeremy Bentham's panoptic device. October 41: 3-29.

Overbeek, H., and B. van Apeldoorn. 2012. Introduction: The life course of the neoliberal project and the global crisis. In Neoliberalism in crisis, ed. H. Overbeek and B. van Apeldoorn, 1-20. Basingstoke: Palgrave McMillan.

Panagia, D. 2010. "Partage du sensible": The distribution of the sensible. In Jacques Ranciere: Key concepts, ed. J.P. Delanty, 95-103. Durham, NC: Acumen.

Polanyi, K. 2002. The great transformation: The political and economic origins of our time. Boston, MA: Beacon Press.

Poulantzas, N. 2014. State, power, socialism. London: Verso.

Rambach, A., and M. Rambach. 2011. Les nouveaux intellos précaires. Paris: Éditions J'ai Lu.

Rancière, J. 1999. Disagreement: Politics and philosophy. Minneapolis, MN: University of Minnesota Press.

Rancière, J. 2011. Staging the people: The proletarian and his double. London: Verso.

Sassen, S. 2000. The global city: Strategic site/new frontier. American Studies 41, no. 2/3: 79-95.

Scott, JC. 1992. Domination and the arts of resistance: Hidden transcripts. New Haven, CT: Yale University Press.

Semetsky, I., and J.A. Delpech-Ramey. 2012. Jung's psychology and Deleuze's philosophy: The unconscious in learning. Educational Philosophy and Theory 44, no. 1: 69-81.

Surin, K. 2010. Socius. In The Deleuze dictionary, ed. A. Parr, 258-60. Edinburgh: Edinburgh University Press.

Wright Mills, C. 1970. The sociological imagination. London: Penguin.

Zizek, S. 2001. Have Michael Hardt and Antonio Negri rewritten the Communist Manifesto of the twenty-first century? Rethinking Marxism 13, no. 3/4: 190-8.

Zizek, S. 2009. First as tragedy, then as farce. London: Verso. 